\title{
Nye fund fra ældre stenalder i Sønderjylland
}

\author{
Af Holger Kapel
}

Det har tidligere været antaget, at Sønderjylland var meget fattig på oldsager og bopladser fra den ældre stenalder. Ved ældre stenalder forstås den periode indenfor den danske stenalder, der spænder fra det tidsrum, da isen efter istiden havde trukket sig så langt tilbage mod nord, at mennesker kunne indvandre og skabe sig en tilværelse som jægere og fiskere - og indtil den slebne $\emptyset \mathrm{kse}$ dukker op, og man så småt begynder at opdyrke jorden, $i$ absolutte årstal spænder perioden over det store tidsrum fra c: $10.000 \mathrm{f}$. $\mathrm{Kr}$. til c: $3000 \mathrm{f}$. $\mathrm{Kr}$.

I Årbøger for Nordisk Oldkyndighed 1913 påpeger Sophus Müller den mærkelige mangel på bopladsfund fra den ældre stenalder i S $\phi$ nderjylland.

I $\gg$ Danmark, Land og Folk $\star 1919$ i bindet $»$ S $\phi$ nderjylland $*$ skriver P. Lauridsen i afsnittet: De s $\varnothing$ nderjydske amter, side 49: \Landets ældste Beboere, de Jægere og Samlere, der efter Istidens oph $\phi r$ indvandrede fra Sydvest Europa, har kun efterladt sig yderst sparsomme Minder ...*

Side 47 i H. V. Clausens rejsebog \$Sønderjylland * (6. udg. 1932) står der: »Ved Åstrup teglværk ude i fjorden eneste bopladsfund i S $\phi$ nderjylland fra ældre stenalder - -

I 1935 og 1936 foretog Nationalmuseet under ledelse af dr. Therkel Mathiassen en række unders $\varnothing$ gelser af bopladser fra stenalderen $i$ hele Jylland. Resultatet af disse unders $\varnothing$ gelser publiceredes 1937 i Aarb $\phi g e r$ for nordisk Oldkyndighed og Historie under titlen: $\gg$ Gudenåkulturen 4 . Vel blev der i denne forbindelse også gjort fund i Sønderjylland, men antallet af såvel oldsager som bopladser fra de s $\not$ nderjyske egne er så sparsomt, at man kunne være tilbøjelig til at antage, at den gamle hævdvundne opfattelse, at den sфnderjyske jord var overmåde fattig på efterladenskaber fra den ældre stenalder, var rigtig. 
Da S $\phi$ nderjylland som bekendt er overordentlig rig på h $\varnothing j e$ fra forskellige perioder af Danmarks oldtid, og da der også er gjort mange sjældne og værdifulde enkeltfund -- jeg beh $\varnothing$ ver blot at nævne guldhornene fra Gallehus - så ser det unægtelig lidt mærkeligt ud, at der skulle mangle betydningsfude bopladsfund fra den ældre stenalder, særlig fordi man må formode, at der alle dage har været en betydelig såvel nord- som sydgående strøm ad den let befærdelige alfarvej fra Nordtyskland op gennem Jylland.

Nu havde Sophus Müller den opfattelse, at alle de gamle fund fra ældre stenalder skulle søges nær kysterne, og han finder forklaringen på bopladsernes fravær ved den landsænkning, der siden stenalderen har fundet sted $i$ den sydlige del af Danmark. Som folge af denne sænkning kunne man med rette formode, at de gamle kystbopladser $i$ vore dage måtte søges under havets overflade langt fra den nuværende kystlinje, en formodning, der også er blevet bekræftet ved fund af ældre stenalders redskaber fra havbunden flere steder i den sydlige del af Danmark.

Imidlertid er der sket meget indenfor dansk arkæologi siden Sophus Müller skrev sin afhandling, store nye fund er gjort fra den ældre stenalder. En stor del af disse er ikke kystfund, men indlandsfund, $i$ de fleste tilfælde dog beliggende $i$ umiddelbar nærhed af daværende inds $\varnothing e r$ eller vandløb, ofte på sandet undergrund. Dette er netop tilfældet med de fleste af den føromtalte gudenåkulturs bopladser.

Engang luftede jeg overfor lederen af Nationalmuseets 1 . afdeling, dr. Therkel Mathiassen, den tanke, at det kunne være interessant at foretage en vandring op gennem Jylland på den jord, der under sidste istid var isfri, for at $\$ \varnothing$ ge efter spor af Danmarks tidligste befolkning.

I marts 1957 meddelte dr. Mathiassen mig, at museet var interesseret $i$, at en sådan undersøgelse blev foretaget, og at der var stillet et beløb til rådighed for mig. Kort efter pakkede jeg mine kufferter og tog til Hjerpsted helt ovre ved S $\varnothing$ nderjyllands sydvestkyst. At det netop blev Hjerpsted, jeg valgte som udgangspunkt, var nu ikke helt tilfældigt.

Professor A. Rust fra Ahrensburg ved Hamburg havde i Kø- 


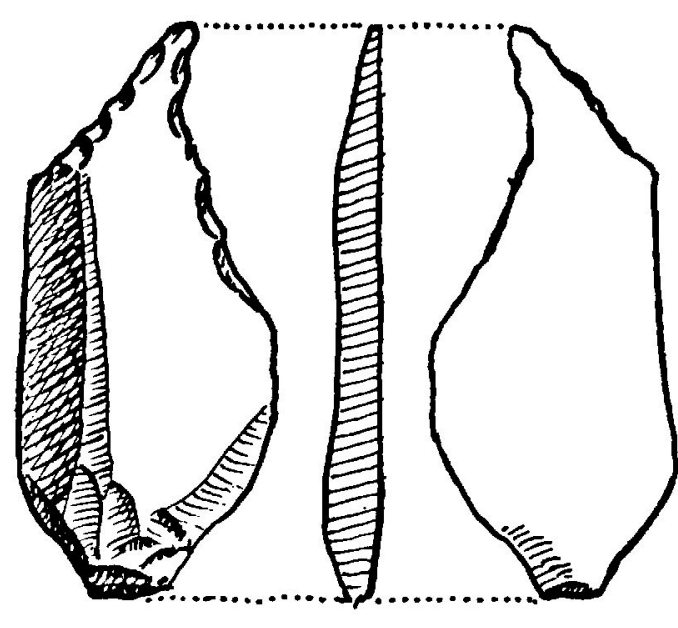

2

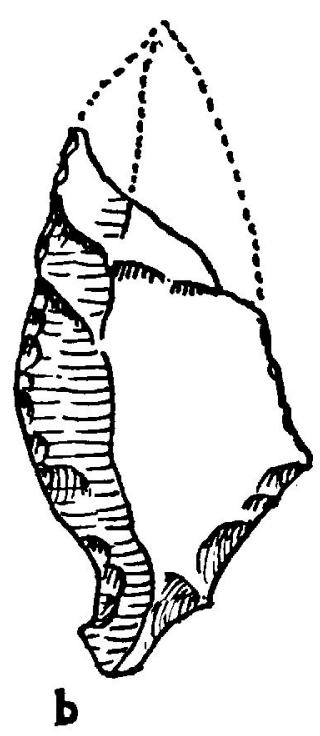

b

Fig. 1. Oldsager fra Albekdalen ved Hjerpsted. Nat. st.

benhavn lige holdt et fængslende foredrag om det tertiære menneskes stenredskaber og heri oplyst, at han $i$ tertiære lag på det Hjerpsted nærliggende Sylt havde fundet sådanne redskaber, og en amatørarkæolog fra Hamburg, Otto Karl Pielenz, mente i strandkanten ved Hjerpsted (ved Emmerlev Klev) at have fundet meget gamle stenredskaber.

Det var med en mærkelig fornemmelse, at jeg gik igang med opgaven, udsendt til en mig fuldkommen ukendt egn på forhånd angivet som blottet for — eller $\mathrm{i}$ hvert fald meget fattig på de gamle stenredskaber, jeg skulle opspore.

Jeg havde $\operatorname{dog} i$ forvejen sat mig $n \varnothing j e$ ind $i$ terrænforholdene på de fortræffelige målebordskort og gjort mig visse forestillinger om, hvor jeg skulle sætte ind, men alligevel, jeg skal ikke nægte, at jeg var lidt nervøs for, at mine anstrengelser og museets mammon skulle være sat ind forgæves.

Det begyndte heller ikke videre lovende.

Tertiærtidsmennesket opgav jeg snart at komme på sporet af, kvartærtidsmennesket skjulte sine efterladenskaber særdeles 
godt for mig. Men så var det, at jeg fandt ind i Albækdalen, der fra kysten syd for Hjerpsted skyder sig et par km øst på ind i landet. Selve Hjerpsted bakkeø, som har ligget udækket af ismasserne under den sidste istid, kan muligvis have udgjort en slags wbrohovede for den senglaciale befolkning, der jagede rensdyret, som sikkert fulgte nordover eftersom isen langsomt trak sig tilbage. I A lbækdalen har rensdyrjægerne utvivlsomt fundet ideelle levevilkår - rigeligt med ferskvand og sandede skråninger ned mod åen. Og senere, gennem hele oldtiden, har befolkningen færdedes her - på mine strejftog ind langs dalen fandt jeg redskaber fra vidt forskellige perioder af stenalderen, og mange broncealderh $\varnothing j \mathrm{i}$ egnen lader formode, at vore forfædre hele oldtiden igennem har følt sig tiltrukket af den. Disse f $\phi$ rste fund fra Ålbækdalen skulle senere blive efterfulgt af andre interessante og gode fund fra andre egne af Sønderjylland. Hele turen varede ialt en månedstid og kom til at dække en strækning tværs over landet fra Hjerpsted til Hellevad med stationer i Hjerpsted, Abild, Løgumkloster og Hellevad. Jeg kunne efterhånden indtegne ialt 36 findesteder på mine målebordskort, ofte kun småfund, men i en større sammenhæng kan selv disse have interesse og få betydning ved senere unders $\phi$ gelser.

Men flere af fundene er dog ret omfattende og sikre vidnesbyrd om bebyggelse $\mathrm{i}$ ældre stenalders tidligste periode, ja muligvis endnu længere tilbage $i$ tiden helt tilbage til den senglaciale tid, slutningen af oldstenalderen (Palæolitikum).

De vigtigste af fundene samler sig om tre egne: Ålbækdalen ved Hjerpsted, terrænet omkring Alslev- Øster Højst og Kongens nose ved Draved skov.

\section{Albækdalen.}

På begge sider af det lille vandl $\phi b$, der risler $i$ bunden af dalen, lokaliserede jeg på de sandede jorder ialt 9 findesteder, muligvis kan et par af dem dog slås sammen til et, det kan undertiden være vanskeligt at sk $\phi n n e$, om man har at gøre med et st $\phi r r e$, sammenhængende fund eller flere mindre, hvor markskel, tilsåning eller beplantning kommer ind $\mathrm{i}$ billedet.

Materialet fra Albækdalen gav et ret suroligt* billede. Jeg op- 


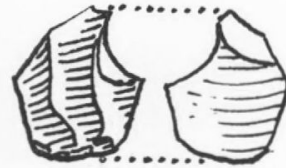

a

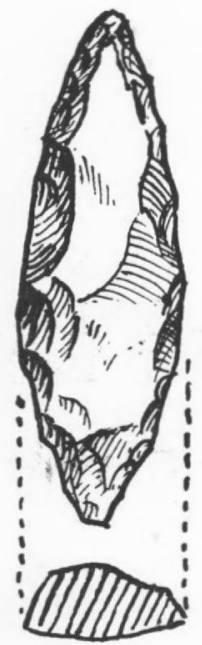

e

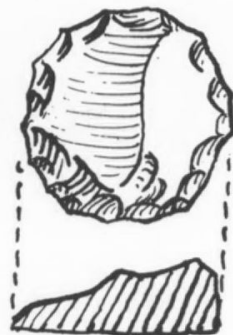

$\mathrm{b}$

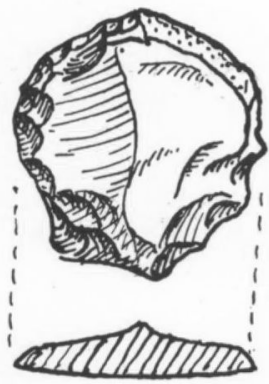

f
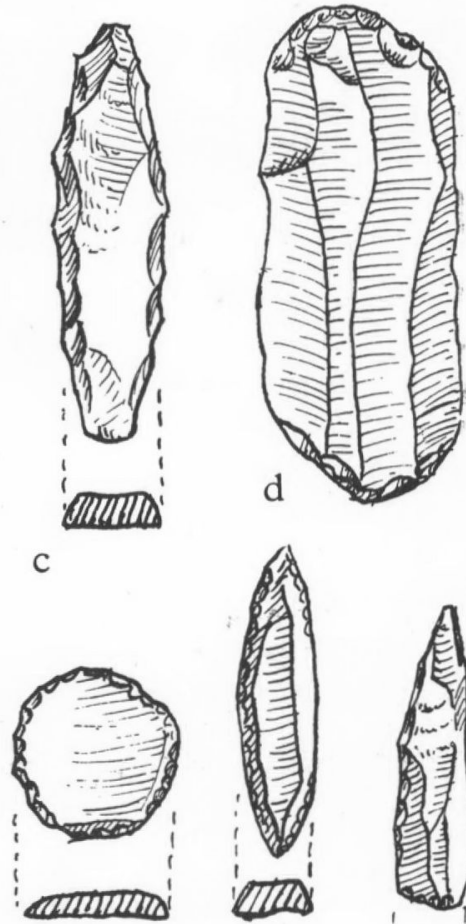

g

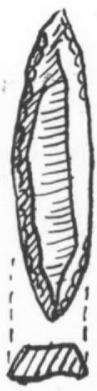

h

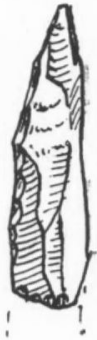

i

Fig. 2. Oldsager fra Albækdalen ved Hjerpsted. Nat. st.

samlede ialt 649 stykker bearbejdet flint, redskaber, forarbejdet og. tilhugget råmateriale. Der er smukt forarbejdede hjerteformede pilespidser, som klart placerer sig sent indenfor den yngre stenalder (18-1500 f. Kr.), muligvis helt op i ældre broncealder, dette gælder også et stort antal store, grove skrabere og brudstykker af slebne $\phi \mathrm{kser}$. Men side om side med disse redskaber forekommer der små, runde skrabere, der utvivlsomt tilhører Maglemosekulturen (c. 6-7000 f. Kr.). Til denne kultur må også henregnes nogle små flintblokke, der er fint tilhuggede som små høvle og skrabere, ligeledes de »mikroliter«, der foreligger. Ved mikroliter forstås små, undertiden bittesmå flintstykker, der ved fin, regelmæssig tilhugning har opnåt ganske bestemte former, tre- 
kanter, lancetter, cirkelsegmenter o. lign. Disse mikroliters anvendelse er ikke helt klarlagt, en del af dem har dog sikkert været anvendt som fuglepile, modhager til fiskeharpuner o. lign. Men det ser ud til, at vi i Albækdalen har spor af endnu oldre kxultur. Fig. 1 viser to oldsager der muligvis går helt tilbage til senglacial tid, den sidste periode af »oldstenalderen «, hvorfra vi i Danmark hidtil kun har et sikkert dateret fund, Bromme ved Sor $\varnothing$, som går helt tilbage til c: $10.000 \mathrm{f}$. Kr. Fig. 1. a, minder påfaldende om de såkaldte $\gg$ Zinker«, kendt fra senpalæolitiske fund i Nordtyskland, særlig egnen omkring Hamburg. Fig. 1 b. er rimeligvis et brudstykke af en skafttungepil, en type der er karakteristisk for Brommekulturen. Hvis min tydning af disse to oldsager er rigtig, skulle vi altså her for første gang i Sønderjylland være på sporet af en senglacial kultur, noget, man med god grund kunne forvente og længe har ventet $p a ̊$.

Flere af de oldsager, der vises på figur 2, har ligeledes et meget gammelt præg, selvom ingen af dem går så langt tilbage som de to stykker fra fig. 1 .

De underlige ten-formede stykker (c, e og h) har jeg lidt svært ved at placere, med deres forholdsvis grove og stejle tildannelse langs siderne minder de dog om senpalæolitiske redskaber. De runde skrabere ( $b-f$ og $g$ ) tilhører nok Maglemosekulturen eller tidlig Gudenåkultur (c. $6000 \mathrm{f}$. Kr.), det samme gælder d, som er en flækkeskraber med udbuet skraberæg i begge ender og $i$, som er en mikrolit af lancettype. Fig. 2. a, er en mikrostikkel, hvorved man forstår et affaldsprodukt fra fremstillingen af mikroliter.

Det er bemærkelsesværdigt, at Erteb $\varnothing$ llekulturens typiske redskaber: kerne $\varnothing k s e n$ og skive $\varnothing k s e n$ ganske mangler, tværpile forekommer ganske vist, men kun i fåtal og de kan ligeså godt

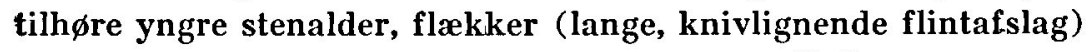
er ikke talrige og må nærmest betegnes som dårlige.

Efter dette synes Ålbækdalen gennem næsten hele stenalderen at have været et yndet tilholdssted for en ret talrig befolkning. At oldsagerne opsamles på markerne i broget forvirring beh $\phi v e r$ ikke at være et minus. Det betyder blot, at flere tidsafsnit er repræsenteret og ved fremtidige unders $\varnothing$ gelser skulle der være 

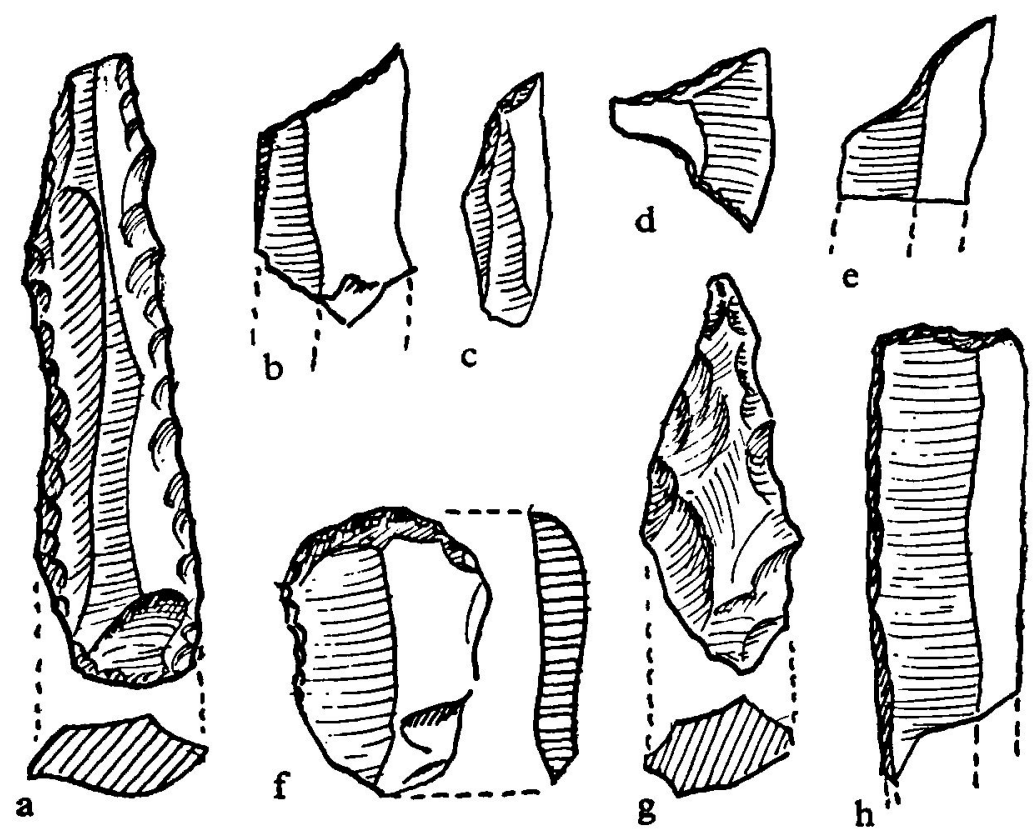

Fig. 3. Oldsager fra Alslen-Øster Hфjst-pladserne. Nat. st.

mulighed for at støde på rene kulturlag lige fra sen oldstenalder til sidste afsnit af yngre stenalder. At den typiske kystkultur, Ertebøllekulturen, (c: $4-5000 \mathrm{f}$. Kr.) helt synes at mangle kunne tyde på, at det afsøgte parti af Ålbækdalen i Ertebølletid lå længere fra havet end tilfældet er $\mathrm{i}$ vore dage, måske havde bakken (der rimeligvis i oldtiden var en bred a) sit udløb i havet et steds mellem Sylt og $\mathbf{R} \phi \mathbf{m} \phi$.

\section{Alslev- $\emptyset$ ster $H \emptyset j$ st-pladserne.}

Mens egnen langs Brede å og Lobæk stort set skuffede mine

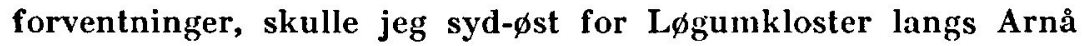
mellem Alslev og $\emptyset$ ster Højst støde på en gruppe bopladser - 6 ialt - der var ret ensartede og havde en helt anden karakter end den, jeg kendte fra Ålbækdalen. Særlig langs åens vestlige bred, fra »Sandet « lige udenfor Alslev lå forskellige gode pladser ret nær ved siden af hinanden. Her dominerede flækkerne, og der 
var ret store og gode eksemplarer imellem. Tværpile og mikroliter var ikke sjældne og små stejlæggede skrabere forekom også. Alle pladserne ligger på sandet terræn jævnt skrånende ned mod åen. De tilhører sikkert alle Gudenåkulturen. Fig. 3 viser forskellige oldsager fra disse fund. a måske en sav, b og e er enten brudstykker af flækkeknive eller forarbejder til tværpile, c en mikrolit, d en tværpil, $f$ en lille skraber, g et bor og $h$ rimeligvis et brudstykke af en stor flækkekniv eller flækkeskraber.

\section{Kongens mose (og Kongsbjærg mose).}

Den sidste gruppe er beliggende på sandet bund i de store moser, der ligger vest for Draved skov, syd for Løgumkloster. Her skærer gravemaskiner for tiden dybe afvandingskanaler, og store, dybtgående plove vender op og ned på overfladen, efterhånden som den tørrer op. Først søgte jeg langs en af disse afvandingsrender, der viste en smuk, klar profil flere meter dyb, og jeg håbede at gøre gode fund i de langs renderne opkastede sandvolde. Resultatet blev negativt. Ikke en stump flint, ikke en dyreknogle, ikke det mindste spor af menneskers eller dyrs tilstedeværelse. Skuffet vandrede jeg så tværs gennem lyngturerne og slog mig ned et sted, hvor lyngen stod noget tyndt på den sandog tørveblandede bund for at sætte min madpakke tillivs. Med min stok rodede jeg lidt op i sandet - men hvad var nu det? flintspåner! Så lod jeg frokost være frokost og kravlede rundt på alle fire og pirkede op, hvor der var åbne pletter $\mathbf{i}$ bevoksningen, - og således begyndte historien om bopladserne i Kongens mose. Det var rent tilfældigt, at jeg fandt frem til dem. På forhånd kunne det synes håbløst at vandre ud på den store flade for at lede efter oldsager, men da jeg først havde fåt farten, fortsatte jeg ufortrøden i dagevis trods regn, storm og kulde og kunne afslutte ekspeditionen med at indtegne 7 bopladser på kortet. Alle disse pladser tilhører utvivlsomt samme kultur. De kan karakteriseres ved mange, ofte gode flækker, enkelte meget primitive kerneøkser, en del mikroliter, blandt hvilke et par større, smukt tildannede stykker minder meget om de såkaldte »penneknive ( Federmesser $«$ ), som tilhører en kulturgruppe, der indgående er behandlet af den tyske arkæolog H. Schwabedissen. 

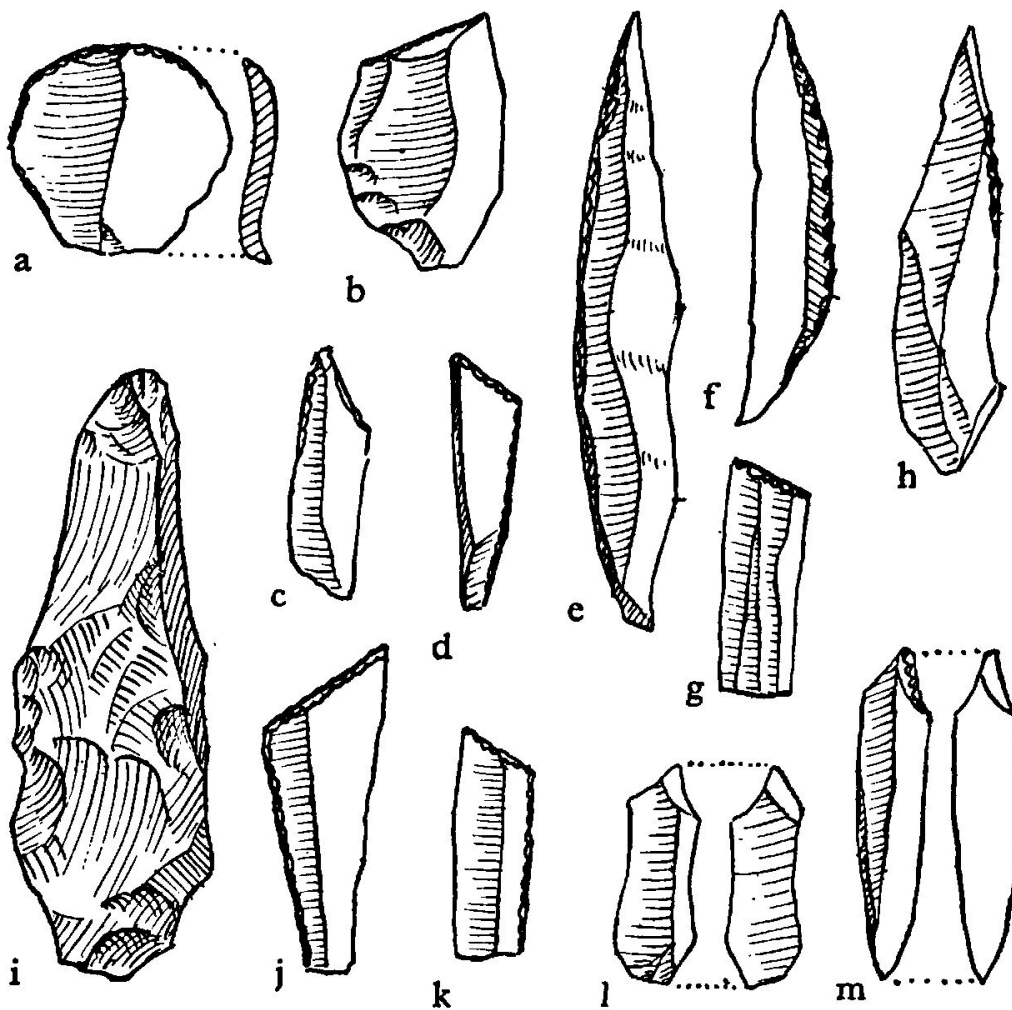

Fig. 4. Oldsager fra Kongens mose syd for Løgumkloster. Nat. st.

Der er også mange af de ovenfor omtalte høvl- og blok-skrabere. Karakteren af disse fund peger bagud til en meget tidlig periode indenfor den ældre stenalder, måske helt tilbage til overgangen fra oldstenalderen. Der er træk tilfælles med den gamle Klosterlundkultur, (c. $8.000 \mathrm{f}$. Kr.) som er beskrevet af dr. Therkel Mathiassen i hans bog om Gudenåkulturen. Fig. 4 viser eksempler på oldsager fra Kongens mose. Man vil se, at oldsagerne er meget mikrolitisk prægede. e er en af de omtalte penneknive, i en kerne $\varnothing \mathrm{kse}, \mathrm{l}$ og m mikrostikler.

Nedenfor bringer jeg en sammenlignende oversigt over de tra- 
ditionelle oldsagstyper fra de forskellige pladser fra min sønderjyske ekspedition.

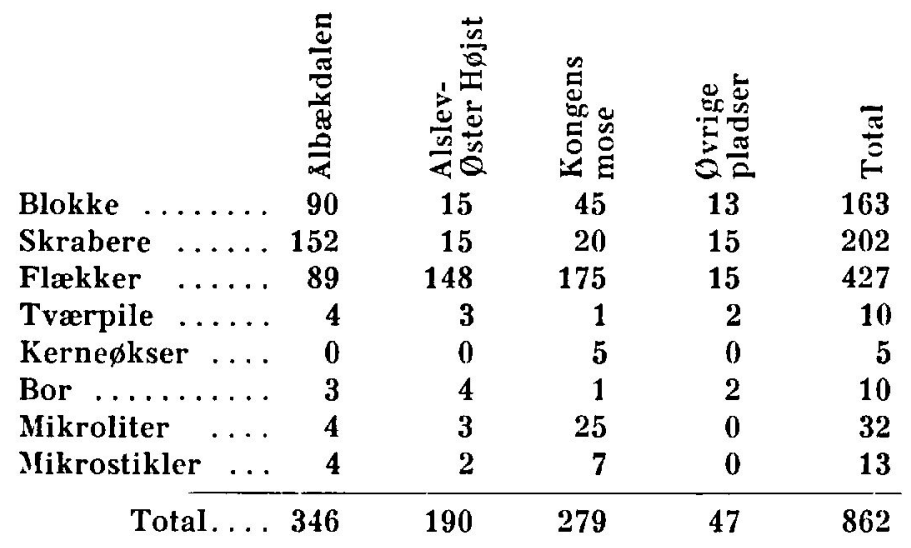

I denne oversigt er ikke medregnet uklare og afvigende typer ejheller det flintaffald, jeg har opsamlet af hensyn til studiet af den tekniske fremgangsmåde ved flintværktøjets fremstilling.

Skemaet giver et ganske interessant billede af de forskellige pladsers særpræg. Det store antal skrabere på Ålbækgruppen peger tydeligt på indblanding fra yngre stenalder, dette fremgår også af, at flækkerne har spillet en underordnet rolle. Fra Alslev og Kongens mose dominerer flækkerne og forklarer de tidlige kulturers behov for flækker. Selvom materialet er for lille til at give helt pålidelige oplysninger, kan man dog med god ret hævde, at Kongens mose-gruppen, som er ren, uden senere indblanding, er ældst - betydelig ældre end Ålbæk-gruppen, selvom der her, som omtalt, forekommer et mindre antal oldsager, der kan gå helt tilbage til oldstenalderen. Alslev-gruppen må sikkert placeres et steds midt imellem, dog utvivlsomt nærmest Kongens mose.

Albækdalen er overmåde rig på oldsager og fortsatte undersøgelser kombineret med systematiske gravninger vil sikkert bringe klarhed i spørgsmålet, om der virkelig findes spor af senglacial bosættelse eller om de af mig indsamlede oldsager rent tilfældigt er blandet ind i senere tiders flintinventar, ja måske blot har en tilfældig lighed med de gamle typer. 
Et synes imidlertid indlysende efter min arkæologiske vandring tværs over den sønderjyske landsdel: bopladsfund fra den xldre stenalder er ingenlunde så sjældne, som man tidligere har troet. Der er god grund til at antage, at fornyede, systematiske undersøgelser vil bringe talrige og betydningsfulde fund for dagens lys, og kan denne artikel bidrage til, at den lokale befolkning i Sønderjylland får $\varnothing$ jnene op for de små, uanselige og hidtil upåagtede mikrolitiske redskaber og meddeler deres iagttagelser til Nationalmuseet eller de lokale museer, så har den ikke været skrevet forgæves.

På min rejse fik jeg indtrykket af, at man netop i disse år har alle betingelser for at gøre store og gode fund. Som i Kongens mose findes der mange steder $i$ den sønderjyske landsdel »dybtgående omvæltninger « sted i moserne, og gravemaskinerne skærer snorlige kanaler i de dale, hvor forhen de vandrige åer snoede sig gennem grønne enge. Disse omvæltninger bør nøje f $\not$ lges af såvel fagarkæologer som den arkæologisk interesserede befolkning, der er overhængende fare for, at værdifulde fund vil gå tabt - eller $i$ bedste tilfælde tabe $i$ videnskabelig værdi, hvis de ikke i tide påagtes og undersøges.

\section{Efterskrift:}

Siden denne artikel er skrevet, har jeg på en studierejse til Holland og Tyskland haft lejlighed til at gennemgå et betydeligt arkæologisk materiale i museer og samlinger, særlig i Groningen og på Gottorp slot i Slesvig.

Efter dette skal jeg indrømme, at jeg med større usikkerhed må se på oldsagerne fig. 1 som senpalæolitiske.

Derimod er min formodning om, at vi i oldsagerne fra Kongens mose står overfor en kultur, der er nær beslægtet med »Federmessegruppen* blevet yderligere forstarket.

På »Biologisch-Archæologisch Instituut « i Groningen så jeg enkelte fund, der faktisk var identiske med de her beskrevne fra Kongens mose. Fremtidige unders $\varnothing$ gelser vil kunne afg $\varnothing$ re, om vi virkelig har at gøre med denne kultur, der ikke hidtil er påvist i Danmark. 